\title{
TOWARD REHABILITATION OF CRIMINALS: APPRAISAL OF STATUTORY TREATMENT OF MENTALLY DISORDERED RECIDIVISTS
}

When an individual becomes socially dangerous, it is necessary for society to protect itself from his acts. The simplest device is merely to isolate the offender. Somewhat more complex, but of more positive value, is the reconstruction of the individual's personality so that he may be permitted to remain within the community. 1 Traditionally, the former course has been pursued, the length of the segregation period being arbitrarily fixed by a preconceived standard of the amount of punishment befitting the particular criminal act. That such penal practice has failed to protect society is indicated by the fact that 50 to 80 per cent of prison inmates serve such periods of incarceration only to commit crimes again upon their release.?

1. For discussion of the conflicting theories, see Barnes, The Stony of Pumszrnes, c. 10 (1930); Elliott, Conflicting Penal Theortes in Statutony Crommal Lan, c. 2 (1931) ; Girlin, Crnitnology and Penologx, c. 13-15 (1935); Waits, Tre Prevention of REPEATED CRRIE, c. 3 (1943); Dession, Psychiatry and the Conditioning of Criminal Justice, 47 YaIE L. J. 319 (1938).

No attempt will be made to enter into the controversy concerning punishment's deterrent effect upon persons other than those punished. See, generally, Sutrernarid, PrumCIPLES of CRIAINology, c. 19 (1939). It has been suggested that "Not the fear of legal penalties, but the fear of loss of status in the group is the effective deterrent," id. at 374 , and that "The best deterrent to crime is a speedy trial and certainty of result." Grimson, Guilty!!-Thens What?, 26 A.B.A.J. 397, 399 (1940). Slirting that battleground, however, the objective in this Comment will be to determine which are the best methods to effectuate the professedly reformative aim of most penal systems. See Asrezrcan Law Institute, Cruartnal Justice-Youtr 11 et seq. (1940); Car. Dept. or Cor-

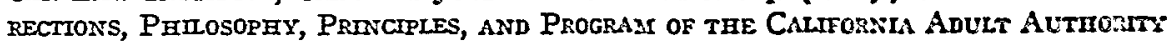
2 (1945) ("Only when prisoners are rehabilitated as well as punished does the penal system solves its problem.") ; Karpman, An Attempt At a Re-ecaluation of some Corcepts of Law and Psychiatry, 38 J. CRnr. L. \& Cnnmology 206, 216 (1947) (if rehabilitation is the end of imprisonment, then emphasis must be on the doer and not the deed).

2. Estimates of the number of recidivists in the prison population are most often drawn from Sellin's study for the American Law Institute, which revealed that 50.5\% of males committed in selected areas had previous institutional records. This figure is subject to two limitations: (1) It is based on previous terms served in some penal institution. As a result, non-institutional penalties such as fines or probation are not included. (2) Identification of prior offenders who have served time in other jurisdictions is far from perfect. Selitin, The Cramtinalty of Youtr 76-S (1940). In some states, recidivists comprise $63-80 \%$ of prison inmates. AMresrcan LAW Instruture, of. cit. stppra note 1, at 9-10. Glueck's long-term study showed recidivism among $85.4 \%$ of his sample group of 1000 juvenile delinquents within the first five years after release. S. As:d E. GLvecrs, Juvenire Delnnguents Grown Up 38 (1940). The Court of General Sessions in Xew York City found recidivists among 50-60\% of defendants. Thompson, A Psyehiglrie Study of Recidivists, 94 Axr. J. Psrchlutry 591 (1937); During the year ending June $30,1939,83 \%$ of youths committed to the N.Y.S. Vocational Institution were previously arrested and $41 \%$ were previously institutionalized. BLANsmand AND LUKAS, Prodatro: 
Among the most glaring examples of statutory persistence in this unsuccessful practice ${ }^{3}$ is the treatment of mentally disordered offenders under the recidivist laws. ${ }^{4}$ Devised to meet the problem of continuing criminality, these statutes offer automatic prescription of increased sentences as a method of dealing with repeated crimes. ${ }^{5}$ Their particular failure to deal effectively

and Psychiatric Care for Adolescent Offenders in NEW York City 53-4 (1942) (high recidivist rate among "severely punished" of all ages demonstrates the "dismal failure of retributive punishment.").

3. This lag is illustrated not only by inadequate statutory revision but also by inadequate classification of offenders, retention of fortress-type prisons as major detention centers, and lack of facilities for cure. To the effect that American criminal law is still dominated by retributive features, see A.B.A. (Section of Criminal Law), Procrams AND COMMITTEE REPORTS 45 (1939) ("The average American penitentiary succeeds as a custodial institution, but is a failure when evaluated in terms of rehabilitating offenders. Punitive theories of justice still characterize too many prison practices.") ; AMERuchN LAw Institute, op. cit. supra note 1, at 12; Kansas Legislattve Council RESEARcir Dept., The Operation of the Kansas Habitual Criminal Law 5 (1936) ("Where commitment is based upon making the punishment fit the crime and where institutional management and parole procedures are based upon making the punishment fit the criminal, there is a maladjustment between commitment, institutional treatment, and release."); Pigeon, Probation and Parole in Theory and Practice 109 (1942) (punishment and reformation are inconsistent and impossible to combine successfully, but both are expected of prisons); WAITE, op. cit. supra note 1, c. 2; Lukas, Comments on the Attitude of the Legal Profession Toward Psychiatry, 5 Law. Gund REv. 301, 307 (1945) ; MacCormick, Adult Offenders in SOCIAL WORK YEAR BoOK 33 (1943) (individualized treatment has remained an unattained ideal because of inadequate funds).

4. Recidivism is defined as "a falling back or relapse into prior criminal habits, especially after punishment." WeBster's New InTERnationat Dictionaky (2d ed. unabridged, 1934). It has too often been used as synonymous with incorrigible habitual criminality. People v. Rave, 364 IIl. 72, 79, 3 N.E.2d 972, 976 (1936). Such incorrigibility has been postulated a priori from the evidence of repeated crime without necessarily being substantiated by experts in criminal behavior. In this Comment, recidivism will be used as defined in Webster's. Where recidivist statutes are referred to, they will include the types of enactments described infra p. 1087 et seq. and footnotes appended.

5. Only "general" recidivist laws, those providing increased penalties for subsequent commission of any of a given class of crimes (generally felonies) will be discussed. Most states have "specific" recidivist laws which add to the original penalty only if the crime which results in a first conviction is repeated. Most criticisms of the former are applicable to the latter. The "general" recidivist laws reached their peak in popularity in the 1920's but measures like them already existed in New York in 1797 and in Massachusetts in 1817. See generally, G. Brown, The Treatment of the Recidivist in the Unitcd States, 23 CAN. B. Rev. 630, 640-2 (1945); Elliotr, op. cit. sttpra note 1, c. 10. The constitutionality of such statutes-once challenged on grounds of double jeopardy, or cruel and unusual punishment, or abridgment of privileges and immunities of a U. S. citizen-is no longer questioned. Carlesi v. New York, 233 U.S. 51 (1914); Graham v. West Virginia, 224 U.S. 616 (1912) ; McDonald v. Massachusetts, 180 U.S. 311 (1901); Moore v. Missouri, 159 U.S. 673 (1895). It has been held that the first offense docs not affect guilt in the subsequent case. Courts speak of it as merely a fact in the past history of the offender which the law considers when fixing punishment for the later crime. Kelley v. State, 204 Ind. 612, 185 N.E. 453, 457 (1933); People v. Sickles, 156 N.Y. 541, 546-7, 51 N.E. 288, 290 (1898). For discussion of its effect on the defendant's presump- 
with mentally disordered offenders may be measured by the continued preponderance of such recidivists among the prison population. ${ }^{\circ}$

As an alternative, contemporary theory recommends individualized treatment based on the dangerousness of the individual and his potential for reform. Such treatment would be focused on recognition that, at least in the case of mentally disordered offenders, repeated crime must be treated as the manifestation of a struggle to preserve mental balance. The success of psychiatry in altering the undesirable behavior patterns of non-criminal neurotics indicates that its techniques may be extended to treatment of those criminal mentally-ill not already hospitalized as criminally insane.?

A program which in effect denies the responsibility of the offender for his own acts by providing for the alteration of his personality structure may present grave problems. ${ }^{8}$ The initial experiments of several states with such procedures, however, suggests that such problems are surmountable, and it appears possible to evolve legal and scientific procedures to preserve traditional safeguards in such a system. Moreover, the existence of a body of psychiatric knowledge suggests the advisability of studying present statutory procedure in the light of alternative psychiatric techniques. Such a psychiatrically-oriented appraisal will assist in developing a better understanding of the nature of crime, which in turn may aid in reforming the penal treatment of all offenders.

\section{Present Statutory Treataient of Recmivists}

Since no special provisions are made for the mentally ill in the recidivist laws, a study of their treatment requires a general review of these statutes. A second factor requiring that a statutory survey be generalized is the impossibility of drawing a sharp line to separate mentally disordered recidivists from other criminals. ${ }^{9}$ But there are substantive advantages to such a broad

tion of innocence, pro and con, see the dissent in People v. Sickles, suspra at 550; People v. Gowalsky, 244 N.Y. 451, 155 N.E. 737 (1927) (validating the Baumes Act providing mandatory life term for four-time felons) ; Note, 14 TEarP. L.Q. 386 (1940).

6. Of several hundred offenders examined by Gregory, recividists were found among $86 \%$ of psychopaths, $36 \%$ of personality deviates. Only $20 \%$ of the normal offenders were recidivists. Gregory, Psychiatry and the Problems of Delinquency, 91 Ass. J. PSYCHIATRY 733, 777 (1935). It has been suggested that mental abnormality plays a considerable part in development of chronic recividism. See Radzinowicz, The Pcrsistcrt Offerder in The Modern Approach to Crarnar Law 171 n. 3 (1945); Bychowsli and Curran, Current Problems in Mcdico-Legal Testimony, 37 J. Crrss. L. \& Crusmrowory 16, 23 (1946) (90\% of recidivists in Belgium are mentally disordered). See, generally, IINDNER, STONE WAILS AND MIEN 336 et seq. (1946).

7. See note 35 infra.

8. See p. 1110 et seq. infra.

9. The theory is that the same forces are at work in abnormal as in normal individuals. The forces differ only in the degree of their intensity. Any attempt to establish categories can succeed only in grading a continuum. See J. Brown;, Psycrodrzinsersos

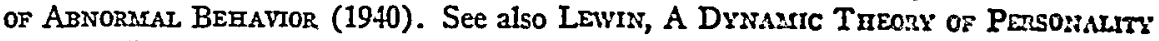
c. 1 (1935). 
review; it contributes to the realization that, to the degree that other criminals possess those characteristics which make penal reform necessary for abnormal recidivists, such reforms are applicable throughout the penal system.

The most important single aspect of the present recidivist laws is their purely mechanical disposition of each case. As a matter of law, longer prison terms are made to follow from commission of two or more crimes. ${ }^{10}$ Although the laws are applied only when the successive crimes fall within the same class-generally labelled "felony" 11 or "penitentiary offense"- in most states, these terms are described so broadly that harsh recidivist penalties are applied for the repeated commission of crimes which do not necessarily mark their perpetrators as serious menaces to society..$^{12}$ Even where the states have attempted to meet this objection by including only specified crimes-e.g. arson, rape, burglary - within the sweep of their recidivist laws, ${ }^{13}$ the basic criticism is unanswered: penal treatment is limited to automatically applied punishment for the criminal act and does not attempt to provide

10. In twenty-nine jurisdictions, a second offender is subjected to double the penalty prescribed for a first conviction of the crime entailed in the second offense; or his sentence is increased by a specific number of years; or, where there are indeterminate sentences, he is subject to higher minimum-maximum limits. For a third conviction, even higher sentences are imposed by twenty-five states. In six of these, life imprisonment becomes mandatory. The other states double or triple the sentence, or follow procedures similar to those indicated for second offenses, except that terms are higher. After the 4th offense, eighteen states make a life sentence possible-thirteen make it mandatory. For a comprehensive review of these statutes, see G. Brown, The Treatment of the Recidizist in the United States, 23 CAN. B. Rev. 630 (1945) ; Note, 48 CoL. L. Rev. 238 (1948).

11. Felonies are defined in most states as crimes which are or may be punishable by death or imprisonment in a state prison. See, e.g., N. Y. Penal LAw \$2. In New York, the class includes assault in the second degree, extortion, false pretenses, attempt to commit second degree larceny, public exhibition of indecent and obscene movies, etc. Sec generally, Mirler, Criminal LAw $41-4$ (1934).

12. A uniform type of detention has been adopted although the offenders are not uniform in make-up. Radzinowicz, The Persistent Offender in TrE MOdern Aprroncri ro Crmminal Law 168 (1945). The law "makes no distinction between a vicious gangster and a casual offender." Doyle, Recent Judicial Modification of Habitual Criminal Act, 23 Dicra 84 (1946). See also Lewis, The Youth Correction Authority Act-A Modcl, 28 A.B.A.J. 322, 323 (1942) ; Metcalf, Recidivism and the Courts, 26 J. Crum. L. \& CrtulNozoGy 367 (1935). The laws of some states require a life sentence for the "repeater" even though the third or fourth offense which marks him as an habitual criminal is only a "misdemeanor." NEv. LAw $\$ 9976$ (Hillyer, 1929) (person convicted of crime of which fraud or intent to defraud is element, or of petit larceny [a misdemeanor], or of felony, who has previously been convicted three times of felonies or five times of petit larceny or of misdemeanors of which fraud or intent to defraud is an element, shall be sentenced to life.); in some states, increased punishment for repeated misdemeanors involving fraud or petit larceny is specified. OkLa. Stat. ANN., tit. 21, $\$ 52$ (1938); WASH. REv. STAT., tit. $14 \$ 2286$ (Remington, 1932) and for misdemeanors "involving moral turpitude." OHio Gen. Cone ANn. § 13457-1, 2 (Page, 1939).

13. G. Brown, stipra note 10 , at $647-8$ and tables at $681-3$. 
cure for such underlying maladjustment as may have produced the act. ${ }^{16}$

This penal practice leads to a number of situations which are clearly contrary to the statutes' avowed purpose of protecting society from crime. ${ }^{15}$ Since life imprisonment can be prescribed in thirteen states only if four crimes within the specified "felony" or "penitentiary offense" category have been committed, ${ }^{16}$ the recognizably dangerous first offender can not be permanently isolated even if it is virtually certain that he will continue to act antisocially. And a "repeater" whose prior crimes were only misdemeanors cannot be long detained even though he demonstrate a pattern of increasing seriousness. ${ }^{17}$ On the other hand, those imprisoned recidivists whose criminal tendencies wane and disappear with advancing years cannot be released until the statutory minimum prerequisite to parole has passed, regardless of the fact that they may no longer be dangerous. ${ }^{18}$

Even in the more progressive states where sentences are not mandatory ${ }^{10}$ and the court is left with some power to fit justice to the particular case, a rigid framework of minimum statutory sentences persists. New York, for example, fixes five years as the minimum sentence for a second or third of-

14. The type and grade of offense is not a good criterion for rehabilitation. See Cantor, Conficts in Penal Theory and Practice, $26 \mathrm{~J}$. Cruss. L. \& Crrsrinolagr 330, 337 et seq. (1935) ; Metcalf, supra note 12, at 369 (classification by offense is unsound because it implies that the commission of the same act by difterent individuals indieates a similarity between them). Such a criterion is especially inappropriate for mentally disordered offenders whose "ungovernable emotions" may lead them to commit a variety of crimes. Wilson and Pescor, Probleass in Prison Psycristry 135 (1939). See also Karpman, An Attentpt At A Re-eraluation of Some Concepts of Law and Psychialry, 38 J. CRIMr. L. \& CrIMINology 206, 207 et seq. (1947).

15. See G. Brown, supra note 10 , at 640 .

16. Life imprisonment for fourth offenders is mandatory in California, Colorado, Florida, Louisiana, Nevada, New Jersey, New Mlexico, North Dalsota, Ohio, Oregon, Rhode Island, Vermont, Wyoming. It is discretionary in Alinnesota, New Yorl;, Pennsylvania, South Dakota. Missouri requires a life sentence upon a fourth conviction of crime while armed with a deadly weapon. See G. Brown, sttpra note 10 , at $650,674-\$ 0$.

17. Specific incidents are related in WATTE, op. cit. supro note, 1, at 31-2, especially 32 n. 29 ; Lewis, stpra note 12 , at 323.

18. A "life-span" theory of criminality has been adianced by S. Aro E. GLuEcrn, Juvenile Delinguents Grown Up 267 at seq. (1940). Their statistics indicate that advancing age witnesses both a decline in criminality and in the seriousness of the offenses perpetrated. Id. at 74,89 . See also Wrottesley, Aftcr-Corduct of Discharged Offenders, 61 L.Q.Rev. 373, 377 (1945). It appears that later years also bring relative sobriety to criminal psychopaths. LINDANER, Stone Walls Axid MIE: 157 (1946).

19. Only eleven of the seventy-two "general" recividist laws in forty-one states and the District of Columbia allow discretion to the court. G. Brown, supra note 10, at 653 . Sixty-one of the statutes specify what the sentence will be and delegate to the court only the duty to declare the sentence. This invasion of judicial sentencing discretion has bren opposed by the courts. Doyle, supra note 12, at 87 (Colorado Supreme Court scrutinizes strictly any prosecutions under recidivist act because it usurps sentencing function). 
fender ${ }^{20}$ and fifteen years for a fourth offender.$^{21}$ Regardless of the adviseability of parole in the individual case, none is possible until the minimum period has elapsed. ${ }^{22}$

The harshness of these laws has led to widespread evasion with its attendant increase in irrational penal practice. Despite ostensible removal of sentencing discretion from the courts in most states, these statutes are invoked only rarely by sentencing judges. ${ }^{23}$ In those jurisdictions where a defendant must be indicted as an habitual criminal if the harsher penalty is to be imposed, prosecutors often fail to bring the charge. And inspired by their natural sympathies, juries have manifested a reluctance to convict and courts to sentence when neither offense nor offender appeared to merit as heavy a penalty as the statute prescribes. ${ }^{24}$ In Kansas, for example, three out of four men eligible for double or life sentence under that state's habitual criminal

20. If the second or third conviction is for a felony which, on first conviction, would be punishable by less than a life term, then an indeterminate sentence is imposed which must be at least half the maximum provided for the first offense and not longer than twice such maximum. The minimum imposed, however, "shall in no case be less than five years." There is an exception to the five year minimum-where the maximum punishment resulting from the above computation is five years or less, then a two year minimum is specified. N.Y. PENAL LAW $\S 1941$.

21. The fourth offender receives an indeterminate sentence; the minimum is fifteen years and the maximum is life. N.Y. PENAL LAW $\$ 1942$.

22. N.Y. CORRECTION LAW $\$ 212$. New York does make probation and suspended sentence available for second and third offenders but.prohibits their use with fourth offenders. N.Y. PENAL LAW $\$ 2188$.

23. In 1929, 757 of 1098 admissions to Sing Sing Prison in New York had criminal histories but only 341 were sentenced as second offenders. Lawes, Crime and Rehabilitdtion, 2 N.Y.S.B.A. Bulz. 19, 23 (1930). See also, G. Brown, stipra note 10, at 658-9. A common evasion of the law was the tendency of New York courts to permit fourth offenders who were not hardened and dangerous criminals to plead guilty to misdemeanors even though they were in fact guilty of felonies. Sargent, Modification of the Batmes Lazes, 4 N.Y.S.B.A. Burt. 340, 341 (1932). New York no longer makes a life term mandatory for fourth offenders. N.Y. PENAL LAW $§ 1942$.

Even uniform adherence to the letter of the law would still leave the statutes at odds with a fact accepted by most students of crime-that those who are first offenders according to police records may in reality have committed many prior crimes for which they were never apprehended or convicted. Gregory, Psychiatry and the Prablems of Delinquency, 91 Ax. J. Psychiatrx 733, 779 (1935). One estimate is 5-10 "jobs" before apprehension. Lawes, sipra at 23. Federal Bureau of Investigation statistics reveal that only 29,171 persons were found guilty of serious felonies in 1940 although an estimated 214,946 were committed-less than 1 out of 7 . These and other statistics on police inefficiency are collected in Barnes and TeEters, NEw Horizons in Crininology 262-6 (1943). A recent extreme example is the case of William Heirins who pleaded guilty to thirty charges when he was first arrested. Kennedy, et al., Psychiatric Study of William Heirins, 38 J. CRIM. L. \& Criminology 311, 341 (1947).

24. G. Brown, supra note 10, at 659 et seq. It has been suggested that "man reacts against too severe penalties" and therefore, fourth offender laws calling for life terms are invoked only under unusual circumstances. Lindner, Stone Walls AND MEN 392 (1946). 
law were sentenced as though they were first offenders. ${ }^{25}$ In some instances the effect has been to subject offenders vith insignificant prior crimes to harsh penalties, while supposedly incorrigible and dangerous criminals may escape their application. ${ }^{26}$ In thirteen states, awareness that habitual criminals might be sterilized may well have further encouraged courts to disregard recidivist laws. ${ }^{27}$

But a satisfactory solution cannot be expected from such unofficial and piecemeal attempts to modify the present recidivist laws, for the source of their error lies in their basic rationale. The automatic increase in severity of sentence for recidivists stems from an uncritical acceptance of the belief that the offender is a free agent whose free will may be acted upon to deter him from further criminality if he is convinced the consequences will be sufficiently distasteful. ${ }^{28}$ Doubt is cast upon the general applicability of such an assumption by statistics which demonstrate a high correlation between

25. Kansas Legistative Council Research Dept., Tae Operation of tae Karisas HABITUAL CRIMTNaI LAw (1936) (uniform enforcement would double the prison population within ten years). Even though recidivists are not sentenced under the applieable laws, their prior records are considered for parole. Id. at 2.

26. Id. at 2. The criticism that the recidivist laws were not "getting the big boys" resulted in the enactment of "Public Enemy" laws. See The War on Crime, 10 Sr. Jon:'s L. REv. 169 (1935) ; G. Brown, supra note 10, at 664 et seq.

27. Thirty states have sterilization statutes, of which thirtcen provide for sterilization of habitual criminals. The laws applying to criminals require 3 finding that criminal tendencies in the particular case are inheritable. Skinner v. OLlahoma, 316 U.S. 535 (1942) (Oklahoma law invalidated because no provision for determination by court of whether individual's children will inherit criminal tendencies). See Kelley, Validity of Statutes Providing for Stcrilization of Habitual Criminals, 4 G৯. B.J., No. 4, p. 81 (1942); Note, 29 VA. L. Rev. 93 (1942). The major criticism leveled at these laws is that, although they profess a eugenic purpose, scientific evidence tends to show criminal traits are not inheritable. Note, 51 YaLe L.J. 1380, 1383 (1942); Barkes and TEETERs, New Horizons in Crminology 172-S1. (1943); Foxe, Heredity and Crime, 36 J. Crins. L. \& Crmmnology 11 (1945); Hawkins, Demographic and Biological Contributions to Sociological Principles in Contearporary Soctal Theory 279, 318-9 (Barnes, et al. 1940). But see Jones, The Social Problcm Gronp, 23 CAx. B. Rvv. 183, 222 (1945).

28. See, e.g., People v. Gowasky, 244 N.Y. 451, 460, 155 N.E. 737, 740 (1927) ("The punishment for the second offense is increased because of his apparent persistence in the perpetration of crime and his indifference to the laws which keep secicty together."); People v. Sickles, 156 N.Y. 541, 548, 51 N.E. 288, 290 (1898) ("The previous punishment having failed to reform him, his guilt . . . is greater, and being so, severer treatment is needed to compel him to reform his ways ...") ; People v. Bergman, 162 N.I: Supp. 443 (App. Div. 1916) ; Blackburn v. Ohio, 50 Ohio St. 428, 438, 36 N.E. 18, 21 (1893). This emphasis upon free will is carried over into statutory interpretation. Thus, to be considered a second offender, the individual must have committed the later erime after he had been sentenced for the first crime. People v. Klemich, 311 III. App. 508, 36 N.E.2d 846 (1941), 26 MinN. L. Rev. 402 (1942); Commonwealth v. Ashe, 339 Pa. 403, 15 A.2d 359 (1940). Two contemporaneous crimes charged in the same indictment do not satisfy the "free will" assumption, apparently because the defendant has not yet had an opportunity to demonstrate refusal to reform. 
adverse environment and criminal behavior. ${ }^{29}$ The presence among criminals of a high incidence of mental abnormality with its attendant irresponsibility (in a medical if not legal sense) further limits the validity of the free will concept. ${ }^{30}$ Surely, possession of a serious personality deviation leaves little room for the operation of "free will".

Despite the criticisms indicated above, the recidivist laws might be deemed justifiable if they had succeeded in protecting society from crime. But such a result has not been achieved. The imposition of additional punishment disregards the fact that even "normal" recidivists have previously been sentenced and have shown they do not respond satisfactorily to incarceration. ${ }^{31}$ Especially among mentally disordered offenders does prison experience, with its unfavorable associations and frustrations, foster a predisposition to delinquency. ${ }^{32}$ These "sick" criminals are not deterred from crime by repeated

29. See note 106 infra.

30. In a study of 1000 juvenile delinquents, $56 \%$ had marked mental, emotional and personality distortions when they were first brought before the court. S. AND E. GLUECK, Juventle Delinguents Grown Up 13 (1940). Generally, 25-40\% of the prison population are said to be mentally disordered. See note 74 infra.

31. Traditional treatment of the recidivist is to increase the severity of his punishment "as if the remedy lay in increasing the dosage of medicine which failed to cure when administered in small quantities." Sellin, Foreword to G. Brown, The Treatmcht of the Recidivist in the United States, 23 CaN. B. Rev. 630, 637 (1945). See also Aschaffenburg, Psychiatry and Criminal Laze, 32 J. CRxs. L. \& Crumnozogx 3, 11 (1941) (the higher the number of former punishments, the quicker the recidivism); SELIIN, TuE CRIMINALITX OF YouTH 116 (1940) (probability of a person's committing a subsequent crime increases with each new conviction). "... [T] he checking of a delinquent carecr once started is no easy matter." HEALY AND Bronner, NEW Light on Dehinguency AND ITS TREATMENT 216 (1936). Of 1000 juvenile delinquents, $85.4 \%$ recidivated during the first five year period after their release, $73.2 \%$ committed crimes during the second five year period, and $66.9 \%$ during the third five year period (at which time they were 29 years old). S. and E. Glueck, Juvenile Dejinguents Grown Up 38, 54,74 (1940). "Every study that has ever been made indicates that if the known criminals between sixteen and twenty-one ... had somehow been prevented by that [first conviction before 21] from continuing a course of crime, the country's total burden of offenses would be a small fraction of what it is. ..." American Law Institute, Crininal Justice-Youtr 7-8 (1940). English experience is similar-70\% of those sentenced were convicted for the first time before 21 and $30 \%$ before 17. Radzinowicz, The Persistent Offender in TuE Modern Approach to Criminal Law 162, 173 n. 1 (1945).

32. A large proportion of crimes arise as reactions to sudden mental stresses; the psychological and penological consequences then combine to drive the offender still deeper into crime. Schmideberg, Psychological Factors Underlying Criminal Behavior, 37 J. CRIMr. L. \& Crmarnotogy 458, 460 (1947). In Glueck's sample group, punishment resulted in a substantially higher proportion of recidivism among mentally disordered offenders than among normal offenders. S. AND E. GLUECK, op. cit. supra note 30, at 113 (see Table 13) ; Editorial Note in Mental Abnoranality and Crime xv (1944) (slowness of English criminal legislation to recognize the existence of a vast number of delinquents who are mentally abnormal has resulted in repeatedly transforming the abnormal offender into a persistent one); Pigeon, Probation and Parole in Theory and Practice: 29 (1942) (imprisonment may permanently affect those who are neurotic or on the verge of mental illness). 
imprisonment, for their crimes are resultants of uncontrollable forces. ${ }^{33}$ Penal treatment which does not succeed in removing or redirecting these forces is doomed to failure. ${ }^{34}$ Fortunately, since psychiatry's major concern has been with mental disorders, there stands ready a body of knowledge which will assist in diagnosing and may succeed in curing mentally disordered offenders.

\section{Psychiatric Diagnosis of Mentally Disordered Offenders}

Basic to the application of psychiatric treatment is an understanding of the psychological mechanisms present in mentally disordered criminals. In explaining these mechanisms, it is necessary to examine the categories traditionally used by psychiatrists: psychotics or "insane",35 mental defectives or feeble-minded, ${ }^{36}$ psychoneurotics, and psychopaths. Since the last two

33. See discussion of criminal behavior p. 1094 et seq. infra.

34. Lindner's contention is that the recidivist is the product of an ongoing process which marks him with certain characteristics. He explains the continued commission of criminal acts as "indicative solely of a compulsion toward the execution of the single ultimate performance which will satisfy the absolute minimum of the demands imposed upon the organism psychologically." LINDNER, Stone Walls ANd MIE: 337 (1946). "Sick" criminals are not cured by incarceration. Nor are others possessed of similar behavior patterns deterred by the punishment of their fellows. And socicty is not protected from them except for the brief period of imprisonment. BLarsanmd asid Lukas, Prodation and Psychiatric Care for Adolescent Offenders in New York Citr 55 (1942). See also Conn, The Psychiatric Treatment of Certain Chronic Offerders, 32 J. Crns. L. \& CrInINology 631 (1942).

35. It is estimated that 7\% of inmates fall within this class. WoOn AND WAIT, CunsE AND ITS TREATMENT 272-3 (1941). Legally insane offenders are committed to hospitals for the criminal insane in most states if their condition is detected. Within the psychotic group, however, are many abnormal criminals who know right from wrong and consequently are legally sane under the MicNaghten rule. See S. Glueck, Psychiotry and the Criminal Law, 14 VA. L. REv. 155, 157-77 (1928). Other psychoties found in prisons are those who develop psychoses during incarceration and those who are not recognized

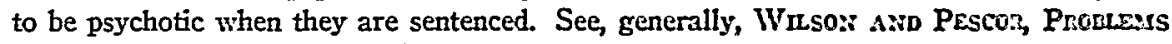
in Prison Psychiatry, c. 8 (1939).

36. Mental defectives-feeble-minded-comprise about $10 \%$ of prisoners. This is in marked contrast to the once widely held belief, stimulated by the Jukes and Kallikal:s studies, that feeble-mindedness and criminality are correlatives. Most studies tcday class the intelligence level of criminals as being on a par with that of non-criminals. Bansirs AND TEETERS, op. cit. subra note 27, at 109, 174-S1; Hartman, Recidizism and Intelligence, 31 J. CRnr. L. \& Crnurnology 417 (1941) ; Bromberg and Thompson, The Relation of Psychosis, Mental Defect and Personality Types to Crime, $28 \mathrm{~J}$. Cris. L. \& Crarnology 70, 74 (1937). There is general agreement that little can be done therapeutically with true defectives. It has been suggested, however, that mentally retarded individuals, who may respond to intensive teaching, are often incorrectly classified as defestives. Even true defectives may succeed in raising their "educational ages." Owens, An Eight Weeks' Experiment in Silent Reading Anong Forly-Threc Unselected Male Adthl Defective Delinquents, 1 J. Crns. Psychopatrology 1 (1939).

The factor which differentiates the criminal defective from the non-criminal is said by some to be emotional. The contention is that his lower intelligence puts him at a disadvantage with his environment and therefore, emotional conflicts may result which lead him to crime. "He is basically a neurotic criminal even though mentally, he is a 
categories contain the majority of mentally disordered offenders, ${ }^{37}$ a substantial number of whom may prove amenable to treatment, study of them has the most general significance.

A psychoneurotic criminal is one whose criminal act is a means of escape from personal anxiety. ${ }^{88}$ His crime is the symptom of his maladjustment. As in non-criminal neurotics, the particular symptoms are generated by conflicting emotional drives interacting with the demands of the environment. Each neurotics' conduct is a means of satisfying certain needs of the organism. When his problem is acted out upon society in such a way as to result in conduct contrary to the penal code, then he is classified as a psychoneurotic criminal. ${ }^{39}$. Such offenders steal as revenge for frustrations, commit acts of violence and robbery as compensation for feelings of inferiority, or seek punishment for unconscious guilt feelings stemming from fancied transgressions or repressed hostility. ${ }^{40}$ Cases of pathological swindlers, pyromani-

defective." Karpman, The Principles and Aims of Criminal Psychopathology, $1 \mathrm{~J}$. Caxu. Psychopathology 187, 196 (1940); see also Coon, Psychiatry for the Lazeyer: Common Psychiatric States Not Due to Psychosis, 31 CoRN. L. Q. 466,479 (1946). See, generally, Lewis, Mental Deficiency and Criminal Behazior in MEntal. Abnomaluty and Crime, c. 4 (1944). Many states provide special institutions for defective delinquents.

37. The most common estimate classes $4-15 \%$ as psychoneurotics, and $15-35 \%$ as psychopaths. Wood and Waite, Crime and its Treatment 270, 274 (1941). For other statistical estimates, see. Barnes and Teeters, NEw Horizons in Criminology 248 (1943); Bromberg and Thompson, The Relation of Psychosis, Mental Defcet and Pcrsonality Types to Crime, 28 J. Crim. L. \& CrImInology 70, 75 (1938).

38. Gillespie, Psychoneurosis and Criminal Behavior in MENTal Annorasality aNd CRIME 72, 85 (1944). Such criminals do not suffer anxieties so long as their criminal activity is undisturbed. Schmidl, Psychological and Psychiatric Conccpts in Criminology, 37 J. Crim. L. \& Criminology 37, 39, 40 (1946). For discussion of psychoneurotic criminals, see Alexander and Staub, The Criminat, the Judge and tue Pudlic (1931). See also Adratandsen, Crime and the Human Mind 104-7 (1944); Wilson and Pescor, Problems in Prison Psychiatry, c. 6 (1939) ; Coon, Psychiatry for the Laweyer: Requisites of a Sound Mental Examination, 26 B.U.L. REv. 272, 282-6 (1946); Foulkes, Psychoanalysis and Crime, 22 Can. B. Rev. 30 (1944); Karpman, An Altempt At a Re-evaluation of Some Concepts of Law and Psychiatry, $38 \mathrm{~J}$. CRIn. L. \& CrnursOLOGY 206 (1947).

39. Fenicher, The Psychonnalytic Theory of Neurosis 505 (1945). The noncriminal neurotic has been said to be a criminal who does not have the courage to commit the crime commanded by his primitive emotions. "He remains a good citizen at the price of developing a neurosis." Karpman, The Principles and Aims of Criminal Psychopathology, 1 J. Crim. Psychopathology 187, 194 (1940). Psychoneuroses are reaction formations against impulses, which if they were overt, would be described as perverted and criminal. Foulkes, supra note 38, at 41 . For discussion of non-criminal neurosis, see J. Brown, The Psychodynamics of Abnormal Behayior 278-80, 351-68 (1940) ; HenDRICK, Facts and Theories of Psychonnalysis (1939).

40. For description of the ways in which these disturbances are transformed, sce Friedlander, The Psychoanalytical Approach To Juvenile Delinguency 116-50 (1947) ; Foulkes, supra note 38, at 40 et seq.; Schmideberg, Psychological Factors Undcrlying Criminal Behavior, 37 J. Crim. L. \& Criminology 458 (1947); Conn, The Psychiatric Treatment of Certain Chronic Offenders, 32 J. Crim. L. \& Crinnotocy 631 
acs, and kleptomaniacs are the clearest illustrations of such reactions. ${ }^{41}$

In contrast to psychoneurotics, criminal psychopaths have been said to be completely unconcerned about the consequences of their acts and to experience no mental suffering. ${ }^{42}$ Comprising the major group of mentally disordered offenders, ${ }^{43}$ they have generally been considered beyond rehabilitation. The resemblance which their symptoms bear to the lay conception of the hardened criminal has caused them to be termed the incurable core of recidivism. Traditionally, they have been described as fundamentally anti-social, incapable of self-discipline or satisfactory emotional relations with others.

But many psychiatrists now contend that the psychopath's lack of concern and suffering is only on the surface; that he is in reality overwhelmed by unconscious internal conflicts. This hypothesis is evidenced by Karpman's study which revealed that in nine out of ten criminals diagnosed as psychopaths, anti-social behavior was traceable to neurotic-like emotional

(1942). A specific case where strong hate reactions stimulated continued crime is discussed in Karpman, From the Autobiography of a Bandit: Tozard Psychogetesis of Socalled Psychopathic Behavior, 36 J. Criss. I. \& CRnonrovory 305, 325 (1945).

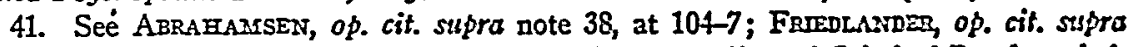
note 40, at 123-32, 139, 148; Karpman, The Principles and Ains of Criminal Psycliopathology, 1 J. Crns. Psychopathology 187, 20 et seq. (1940) ; Lorand, Comprustive Stcaling, 1 J. Crtas. Psychopathology 247 (1940). See also Selling, The Psyehofalisology of the Hitand-Rus Driver, 98 Axr. J. Psychlatry 93 (1941).

42. "Psychopaths are heartless, conscience-less, unprincipled, sense-of-guilt-less individuals ... incapable of sacrifice for others." Although they are often intelligent, they cannot utilize their intelligence for socially useful purposes. Karpman, The Principles and Ains of Criminal Psychopathology, 1 J. Crrar. Psychopatrouogr 187, 189 (1940). Unlike a mental defective or legally insane individual, the psychopath can foresce the consequences of his acts in their outer aspects. But he doesn't care enough about consequences. LINDNER, Stone Walls AND AIEN 164 (1946). It has been suggested that they are not responsible for their actions and therefore, they should be classed among psychotics (1) for protection of society (2) for treatment purposes. CuEcriey, THE MLAST of SANITY 258 et seq., 293-4 (1941). Some observers think that psychopathy is a condition toward which the individual is predisposed biologically, but which vill not develop unless precipitated by environmental pressures. LiNdNER, op. eit. supra at 156 ct seq. See generally, Henderson, Psychopathic States (1939); Lindaner, Rejel Without A Cause 1-14 (1944) ; Diethelas, Treatarent in Psychiatay 395-S (1936) ; Coon, Psjechiolry for the Lawyer: Common Psychiatric States Not Due To Psyehosis, 31 Cosn. L. Q. 466 (1946) ; Schmideberg, stpra note 40.

43. A review of several studies indicates that $15-35 \%$ of prison inmates are psychopaths, although some estimates are even higher. WOOD AND WVAITE, op. cif. sipre note 37 , at 269 . Another estimate is that $69 \%$ are included within this group. Brombers and Thompson, supra note 37, at 75. But Henderson calls their estimate a conservative one. “... the proportion of psychopathic states, not only among the prison population, but in ordinary social life, is very high indeed .. ." HeNderson, PsYCHOPATIIC States 42 (1939). Of 361 psychopaths in Gregory's clinic, $86 \%$ were recidivists. Gregory, Psychialry and the Problenzs of Delinquency, 91 Axr. J. Psychutrey 773, 777 (1935).

44. Scender, Psychotmerapy 62, 290 el seq. (1938); Aitler, A Plea for Selective Psychiatric Treatment for Offenders, 37 J. Crac. L. \& Crmmrocogy 377 (1947) (socially 
difficulties. ${ }^{45}$ The "true psychopath," according to Karpman, is merely the one case in ten whose maladjustment is not discoverable in our present state of knowledge.46 Accordingly, the "psychopath" category appears to be an over-used repository for those offenders who are actually mentally disordered but who cannot be easily classified or treated. ${ }^{47}$ This confusion in terminology has tended to obscure the fact that the behavior of criminal "psychopaths" often has a neurotic basis. ${ }^{48}$ It has even been suggested that habitual criminality, so often attributed to incurable psychopathy, is a specific form of neurosis. ${ }^{49}$ The existence of the "neurotic" factor in the psychopath, even though more difficult to reach than in the ordinary psychoneurotic criminal, enables him to be treated psychiatrically. ${ }^{50}$

frustrating factors account in large part for the hostility and aggression turned against society by such individuals); Schmideberg, stupra note 40 , at 462 .

45. Karpman, The Principles and Aims of Criminal Psychopathology, 1 J. Crnur. Psychopathology 187, 198 (1940); Schmideberg, sulpra note 40, at 471, found a neurotic basis for the behavior of each of fifty psychopaths treated. See also Karpman, From the Autobiography of a Bandit: Tozuard the Psychogenesis of So-Callad Psychopathic Behavior, 36 J. CRIM. L. \& CRIMINology 305 (1945). This deep-lying neurotic basis in most psychopaths has resulted in their being called "neurotic characters" by many psychiatrists. J. Brown, Psychodynamics of Agnormal Benavior 399-401 (1940) ; FENICHEL, op. cit. silpra note 39, at 373 et seq., 504 et seq.; AdRAMAMSEN, op. cit. supra note 38, at 107 et seq.

46. Karpman, An Attempt At a Re-evaluation of Some Concepts of Lant and Psychiatry, 38 J. Crim. L. \& Criminology 206, 216 (1947). There is little hope of sticcessfully treating this group. Removal from the home environment and long-range re-education may help but it is doubtful. Diethelas, op. cit. sitpra note 42, at 398; FriedLander, op. cit. supra note 40 , at $138-9$.

47. Schmidl, Psychological and Psychiatric Concepts in Criminology, $37 \mathrm{~J}$. Cris. L. \& CRTMmNology 37, 42 (1946). "Borderline psychotics, sexual perverts, hoboes, drunks, drug addicts and a host of other misfits who can't be pigeonholed elsewhere find themselves labeied psychopaths." Wirson and Pescor, Problems in Prison Psychintry 122 (1939). The last-named writers suggest that almost every psychiatrist has his own idea of psychopathy: some class all criminals as psychopaths; some reserve the term for prison disciplinary problems; others reserve it for offenders with little prospect of rehabilitation. Id. at 134. "The conception . . . is as vague and as open to misinterpretations as was the former conception of 'moral insanity'" FrIEDLANDEk, THE PsYcroanalytical Approach to Juvenile Delinguency 138 (1947).

48. It is suggested that it would be preferable to describe psychopathy as a bchavior rather than a constitutional disorder, "for it is thereby not necessarily implied that such individuals are practically incorrigible." Miller, $A$ Plea for Selective Psychiatric Trcatineut for Offenders, 37 J. CRIM. L. \& CRIMINoLogy 377 (1947).

49. Karpman, An Attentpt At a Re-evaluation of Some Conccpts of Law and Psy. chiatry, 38 J. CRIM. L. \& CRIMinology 206, 216 (1947) (the greater percentage of habitual criminals show definite emotional motivations for their crimes); Karpman, The Principles and Ains of Criminal Psychopathology, 1 J. Crim. Psychopatrology 187, 199,210 (1940).

50. Where crime is based on definite emotional motivations, it can be reached psychotherapeutically, sometimes with little difficulty. Karpman, An Attempt At A Re-cvaluation of Some Concepts of Laze and Psychiatry, 38 J. CRIM. L. \& Crimrnologr 206, 216 (1947). 


\section{Psychiatric Cure of Mentally Disordered Ofrenders}

Since criminal and non-criminal mental disorders are generated by the same forces, treatment techniques developed by psychiatry for the cure of the mentally-ill are equally applicable, regardless of the patient's criminality. A review of these methods suggests the possibility of their incorporation into the penal system. The most promising of these techniques are: psychosurgery, psychoanalysis, hypnoanalysis, suggestion therapies, and group psychotherapy.

\section{Psychosurgery}

Although rarely used as a method of treatment for non-organic disorders, psychosurgery has startling implications for rehabilitation. ${ }^{81}$ Based on the ability to "cut out cares," the development in this field of greatest potential significance is the pre-frontal lobotomy..$^{52}$ This operation, which severs the connection between the intellectual and emotional centers of the brain, reportedly results in the elimination of anxiety. ${ }^{53}$ Although used with startling success recently in eliminating the "criminal tendencies" of prison inmates with long criminal histories, ${ }^{54}$ these operations have been attended by a

51. In addition to psychosurgery, the principal non-psychological techniques used to treat mentally disordered offenders are the shock therapies-insulin, metrazol, and electric shock. These techniques are used primarily with schizophrenics and manic-depressives who fall within the psychotic category and generally are classified as legally insane. Psychoneurotics are almost never subjected to such treatment. See Fenicher, Tre Psycronxinlytical Theory of Neurosis 568 et seq. (1945); J. Brown, Psychodrinanics of AfNORMLAL BEEAVIOR 63-4, 324-5, 331-2 (1940).

52. See Freeman and Watts, An Interpretation of the Functions of the Frontal Lobe -Based Upon Observations in Forty-Eight Cases of Pre-fronfal Lobofomy, 11 YaLe J. Bro. \& MED. 527 (1939) ; Strecker, Pharmacological and Surgical Approaehics in TuERApeutic Advances in Psychiatry 6 (1941); Cutting Out Cares, Newsweer, Mray 20, 1946, p. 64. A more recent discovery is the topectomy, also a brain operation. According to doctors who have worked with it ". . . there is no evidence of deterioration in social behavior. ... One of the unpleasant features of lobotomy ... is that after the operation a patient might have an essentially different personality." Thus far, this technique has been used only with psychotics (twenty declared fit for discharge out of twenty-four treated). N. Y. Times, Miarch 19, 1948, p. 25, col. 5.

53. The surgeon severs the brain fibers connecting the frontal lobes, which plan desires, and the thalamus, which expresses those wishes emotionally and translates them into action. N.Y. Times, Dec. 7, 1946, p. 34, col. 4. The frontal lobes "assemble the available data, synthesize them, plan a course of action with the ideal in mind, and, equipped with energy of response and with appropriate affective tone, project the individual into the future, direct him toward his goal-and criticize his shortcomings." Freeman and Watts, supra note 52 , at 538 .

54. The operation was performed in Detroit on a woman who had spent 14 years in penal institutions and whose record included almost every type of crime. One month after the surgery, the psychiatrist reported that "She is more relased, more composed emotionally ... Her former threatening, aggressive, assaultive behavior has disappeared. In contrast to her previous defiant attitude she shows genuine embarrassment about her past conduct. It is hoped that [this procedure] will cause the abpormal desires 
relatively high mortality rate. . Thus, there is need for considerable improvement in technique before they can be applied on a large scale in the prison system. But the history of researches with this method of treatment indicates that fatalities are being avoided and it is proving successful in an increasing number of cases. ${ }^{55}$ Perfection of so relatively simple and inexpensive a rehabilitative technique as the prefrontal lobotomy promises to be a major contribution to the cure of criminals.

Psychoanalysis

In contrast to the physiological approach of psychosurgery, the majority of techniques used to combat mental disorders short of insanity are purely psychological and may be grouped under the heading of psychotherapy. ${ }^{\circ 0}$ Psychoanalysis, ${ }^{57}$ the best known of these methods, bases its treatment on the theory that both symptom and disease will disappear if the patient is "analysed"-led back over his past so that disabling conflicts may,reappear

of this patient to either disappear or lie dormant ... instead of being expressed, in actual behavior." N.Y. Times, Dec. 7, 1946, p. 34, col. 5. In Pittsburgh, a psychopathic personality who had spent fifteen of his thirty-eight years in prison, was cured of his "criminal tendencies." The operating psychiatrist recommended to the court that if lasting results were desired, the offender would have to be set free to begin the relearning process in a normal environment. The sentencing judge did not accept the psychiatrist's recommendation and the offender remained in prison. See Crime Cure?, TIME, July 14, 1947, p. 53.

55. Where the prefrontal lobotomy has been used with advanced -schizophrenics, the class of psychotics who are least responsive to treatment, the results have been discouraging-of 17 such patients at the Mantano, Illinois State Hospital in 1940, 2 died and 15 showed no significant improvement. 'Results at the Elgin, Illinois State Hospital were considerably better. There, less serious cases (non-psychotics) were selected. Of 45,25 showed definite improvement (12 were able to be sent home), 13 remained unimproved, and 7 died. See Lobotomy, 38 J. CrIm. L. \& Crininology 392 (1947).

56. Psychotherapy seeks to change the mental condition of the individual by treating, not some part of the patient's body, but the individual as a whole. The treatment functions through speech, perceptions, thinking, emotions, and relationships with others. It may be defined as "the provision by the physician of new life-experiences which can influence the patient in the direction of health." Levine, Psychormerapy in Medical Practice xii (1942); see also W. Brown, Psychological Metrhods of Henling, c. 1 (1938).

57. Psychoanalysis, theory and practice, has been the subject of a vast amount of literature. The writings of Freud are, of course, basic to a thorough understanding. See his General Introduction to Psychonnalysis (1920) for a relatively non-technical presentation of his views. See also J. Brown, Psycriodynamics of Adnormat BEmavior (1940); W. Brown, Psychology and Psychotherapy, c. 4, 5 (1940); HenDRICK, Facts aNd Theories of Psychoanalysis (1935). For discussion of the criminal from a psychoanalytic viewpoint, see Alexander and Staub, The Criminal, The Judae, AND THE Punlic (1931); Foulkes, Psychoanalysis and Crime, 22 CAN. B. Rev. 30 (1944) summarized in 108 Just. P. 399 (1944); Mullins, Crtnse and Psychology, c. 1 (1944). For description of treatment method, see Diethelar, Trentment in Psyciratry, c. 4 (1936) ; Feniched, The Psychoanalytical Theory of Neurosis 569-82 (1945); Levine, op. cit. silpra note 56, at 139-52; Neustatter, Modern Psychology in Practice 224-34 (1937). 
in their original setting. ${ }^{5 s}$ Once confronted with his hitherto unrecognized problem, the patient is often able to develop a mature insight which may permit him to redirect the energy previously expended in criminal activity into socially acceptable channels. 53

Psychoanalysis was used with a great deal of success by Alexander and Healy in their studies of selected recidivists who had already spent many years in reformatories and prisons. ${ }^{60}$ But this treatment suffers from the disadvantage of requiring two to three hours a week for at least a year for each subject, and therefore is impractical on any large scale in our prisons. As a result, most observers feel that it should be reserved for especially difficult cases not curable by any of the simpler psychotherapeutic techniques. ${ }^{\text {al }}$

\section{Hypnoanalysis}

Based upon the principles of psychoanalysis, hypnoanalysis similarly purports to cure the disease rather than the symptom alone. ${ }^{22}$ By using hypnosis instead of the free association method employed in psychoanalysis, it attempts to cut down considerably the time involved in eliciting the information necessary for giving the patient an insight into his problem. Lindner, applying hypnoanalysis to six chronic recidivists (classified as psychopaths) succeeded in curing them in a maximum of four months, during which time he devoted two to three hours a week to each case. In all of these instances there was no subsequent relapse into criminality.03

58. Information is elicited from the patient by means of "free association." "[T]his method is based upon the assumption that when the individual is relieved from the necessity of logical thinking and reports everything going through his mind he will necessarily, under the pressure of emotions which tend to expression, bring forward basic material. ... This method therefore tends to a liberation of deeper layers of psychic life. . . " ScHilier, Psychotherapy 21 (1938).

59. Psychoanalysis works by making the rational component of the individual face its underlying conflicts "in their fuil emotional value by undoing the opposing defensive forces, effective as 'resistances', through the interpretation of derivatives and especially of the derivatives expressed in the transference [the relation of the patient toward the analyst]." Fenicher, The Psychoanalytic Theory of Neurosis 573 (1945).

60. Alexander and Healy, Roots of Crnare (1935). For discussion of this research, see Foulkes, stipra note 57 , at 43 et seq.

61. ". . amongst adult offenders, those cases in which neurotic symptoms are most pronounced ... should be considered for psychoanalytical treatment. ..." These include cases of kleptomania, incendarism, certain sevual offenses, and "neurotic characters" (psychopaths with a neurotic basis referred to in note 48 supra). Frreblatidan, TuE Psychoanalytical Approach to Juvenile Deirnguescy 208 et seq. (1947). The opinion has been expressed that the difficulties confronting the use of psychoanalysis with criminals should not prevent its being experimented with systematically. S. GLuEcr, CRINIE AND JUSTICE 244 (1936).

62. For a description of the method used in hypnoanalysis, see Lr:orer, REsec. WITHOUT A CAUSE 15-24 (1944). He contends that hypnoanalysis tends to verify the insights into "behavior dynamics" contributed by psychoanalysis, id. at 226. The major part of the volume is devoted to a stenographic record of the conversations between Dr. Lindner and his criminal psychopath patient.

63. In regard to brevity of treatment and persistence of benefits of treatment, see 


\section{Less Intensive Therapies}

The less intensive forms of psychotherapy neither probe as deeply nor devote as much time to each patient as is required in psychoanalysis or hypnoanalysis. Instead of attempting to get at the roots of the maladjustment by tracing it back to its origin, these simpler techniques concentrate upon eliminating the external symptom-the mental anxiety or criminal activity. ${ }^{04}$ The physician takes a much more active part in the treatment process than does the psychoanalyst,"by means of conversations which permit the "mental ventilation" or airing of long repressed anxieties; ${ }^{65}$ suggestions, including post-hypnotic suggestion; ${ }^{66}$ environmental reorganization on the familial, occupational, or recreational level ; ${ }^{67}$ or combinations of several of these techniques. The objective is only to strengthen the patient's ability to resist the neurotic forces which were expressed in his criminal behavior. By contrast with the thrust of the "deeper" analytic therapies, no attempt is made to give the patient an understanding of the intricacies and sources of his psycho-

id. at 18, 286. According to Lindner, cured in an analytical sense means not the mere removal of the symptom but a diversion of psychological energy requiring personality transformation. Where there is no cure in this sense, analysis enables the patient to live with his condition. Both are based on giving the patient insight and reorienting his attitudes and aims. Id. at 287. But compare Fenichel, The Psychos nalytical Theory of NEUROSIs 563 (1945).

64. "Symptomatic treatment and adjustments are frequently the best we can expect. A far-reaching analysis leading to a fundamental adjustment may be impossible when one deals with inadequate personality assets, insufficient intelligence, lack of time." DiETuELM, Treatment in Psychiatry 331 (1936); Fenichel, op. cit. supra note 63, at 554-67. Sce also Levine, Psychotherapy in Medical Practice 62 et seq. (1942).

65. This is the simplest technique-the patient talks his troubles out and thereby releases emotional tension. Difficulties may be disclosed which are correctible. WirsoN and Pescor, Problems In Prison Psychiatry 114 (1939).

66. Suggestion (prohibition or encouragement of certain courses of activity) requires considerable effort and skill on the physician's part. WILsON AND PESCOR, op, cit. supra note 65 , at 114. Some who use this technique do not claim that it produces basic personality changes. Nevertheless, it can often succeed in removing the symptom-the antisocial behavior. One psychiatrist found that a short analysis, followed by post-hypnotic suggestion (given while the patient is in a hypnotic state, it will almost invariably be complied with after the hypnosis has passed) was effective with many neuroses. Forgers, auto-thieves, hold-up men, alcoholics and sex delinquents were most responsive. Newkirk, Psychotherapy on Juvenile Delinquents, 34 J. Crins. L. \& Criminology 100 (1943). See, generally, DiEthesss, op. cit. supra note 64, at 44-60,332; NeustatTer, MOdern Psychology in Practice 237-40 (1937).

67. The maladjustments in many cases are attributable to unwholesome family backgrounds or poverty. See note 108 infra. To send the offender back to such an environment is to invite a repetition of crime. Thus, Healy and Bronner recommend placement of young offenders in foster homes; and Lindner suggests trade-training for cconomically desirable occupations. See note 91 infra. Levy, citing Hemphill, suggrsts the value of recreational therapy "which aims at directing the patient to recreational pursuits prescribed by physicians to meet the unconcious needs of the individual." LEVY, REDUCTION Op 1 Recidrisas Through Therapy 140 (1941). For discussion of environmental methods of 
logical problems. As a result, critics of the simpler techniques claim that they remove only the symptom and leave the unconscious problems free to manifest themselves in new forms. ${ }^{63}$

But there are many who insist that even these less intensive methods can achieve lasting cures, ${ }^{69}$ a contention which may be borne out, at least when a modified analysis is used..$^{70}$ In such a technique, the analyst supplements the active role required of physicians in the less intensive therapies with psychoanalytic knowledge. The technique entails a combination of a limited degree of interpretation, provision of well-chosen substitute outlets, suggestion or prohibition of certain courses of activity and alterations of the environment..$^{71}$

\section{Group psychotherapy}

Although still in its infancy, group psychotherapy was used in criminal rehabilitation centers in World War II and promises to be highly suitable for prison application. It has been suggested that the mental disorders which produce anti-social behavior may be derived from failure to experience constructive group relationships. ${ }^{72}$ An attempt to fill this experiential void is made in group treatment. ${ }^{73}$ The individual is not isolated with the physician

treatment, see Friedlander, The Psychoaisuytical Appronca to Juvenille Dehl:iQUENCY 237-64 (1947).

68. The advantage of suggestion and hypnosis is its brevity. However, it does not prevent the development of new symptoms. FrIenLaNDER, op. cit. supro note 67 , at 220 . “. . . the patient may produce a new 'substitute neurosis' . . . cure by 'increase in repression' would have turned into a cure by "establishment of nev derivatives'. . . FEsicaE, op. cil. supra note 63 , at 556. It may cure the hysterical symptom but will not cure hysteris itself. Howe, Motives and Miechanisars of the Mínd 240 (1931).

69. See e.g. Dietreins, Treatarent In Psychiatry 54-5 (1936) who says that the reason for the reappearance of symptoms is that most physicians are not aware of the more recent developments of therapeutic hypnotic techniques. "They still believe that it is merely necessary to give suggestions for a symptom to disappear and not recur. This purely symptomatic treatment is insufficient. In order to give well planned suggestions, the whole reaction and the personality setting must be understood." Ibid. Suggestion and hypnosis are very valuable in cases of minor disturbances but are not successful in chronic neurotic cases. Frienlander, op. cit. stipra note 67 , at 220.

70. Karpman, The Principles and Aints of Criminal Psychopathology, $1 \mathrm{~J}$. Crns. Psychopathology 187 (1940) ; Neustatter, op. cit. supra note 57, at 249. The length of this modified analysis is two one-hour sessions weelly for one month to one year. See DIETHELM, op. cit. supra note 69, at \&6-133 for modifications of psychounalysis.

71. See Fenicher, op. cit. supra note 63 , at 564 et scq.

72. Miller, $A$ Plea for Selectize Psychialric Trealment for Offenders, 37 J. Crrs. I. \& Craminology 377, 379-81 (1947).

73. As practiced in U.S Army rehabilitation centers, group therapy utilized lectures and open discussions conducted by men with common problems; neurotics formed one group, psychopaths another. Berlien, Rehabilitation Center: Psychiotry and Grons Therapy, 36 J. CRIMr. I. \& Crminology 249, 255 (1945). The objective of treatment is to effect changes in the individual's social conciousness by exposing him to group influence. See Sraver:; An Introduction to Group Therapy 2, 312 (1943) ; Friedrastoer, The Psychonsialiti- 
as in orthodox methods. Instead, he is placed in a group composed of offenders possessing maladjustments like his own. The members of the group discuss mutual problems, reactions to specific situations and outlooks on life. A dual function is served by these discussions: the individual is enabled to discharge long pent-up emotional pressures; at the same time, his exposure to the difficulties of persons like himself results in a deeper insight into his own problems. With the indirect assistance of a trained group leader, the offender is encouraged to subordinate his individual problems to the more important needs of the group. The overall pattern is one of guidance towards socially acceptable behavior.

\section{Towards A More Rehabilitative Approach}

Even a brief survey reveals that incorporation of psychiatric techniques into the penal system would aid in the rehabilitation of the 25-40 per cent of the prison population who are mentally disordered..$^{74}$ Moreover, application of psychiatric treatment to the mentally-ill first offender would significantly decrease the probability of his becoming a recidivist. According to one estimate, he would be "three times more likely to be successful at the expiration of sentence than the same kind of case without special treatment." ${ }^{75}$ Where psychiatry is unable to provide a cure, its diagnostic pro-

Cal Approach to Juvenile Delinguency 220 (1947). The value of group treatment for criminals patterned after that in use in mental hospitals is indicated by Scurlder, Psxcriotherapy 157, 197 et seq., 296 (1938) ; Diethela, Trentarent in Psychintik 34-6 (1936); Foulkes, supra note 57 , at 60 reports encouraging results from his use of group therapy with neurotic criminals. He believes such an approach possesses greater therapcutic possibilities than individual analysis. For a detailed description of this treatment as applied to problem children, see SLavson, supra (see especially pp. 312-34 for summary of variations in technique and applications to adults).

74. This figure is the one most widely used. Psychiatric diagnoses do not always correspond, however, and therefore, estimates of mental abnormality in the prisons have ranged from 7-77\%. Barnes and TeEters, New Horizons in Criminology 248 (1943). See also Blansaard and Luras, Probation and Psychiatric Care For adolescent Offenders IN NEW YoRK CITY 56 (1942) (71\% of those admitted to Sing Sing Prison in 1941 mentally disordered); Bromberg and Thompson, The Relation of Psychosis, Mental Defect and Personality Types To Crime, 28 J. Crim. L. \& Crimrnology 70 (1938) (17.7\% mentally disordered among those convicted in Court of General Sessions of New York City). One writer points out that among offenders against property, who comprise more than threcfourths of all criminals, there is a high percentage of abnormality. Editorial Note in MENTAL Abnornsality and Crime xvii (1944). .

75. Selling, The Psychopathic Clinic in a Criminal Court, 28 J. Arr. Jud. Socx. 169, 172 (1945). Recidivism among those who have completed treatment is rare. Of 102 cases treated in 1941 at the English Institute for Scientific Treatment of Delinquency, only nine were subsequently delinquent. Of the cases who were given any psychiatric treatment at all (even if not completed), an average of $40 \%$ remained non-delinquent. Glover, The Diagnosis and Treatment of Delinquency in Mental ABnormality and CRMMe, c.12 (1944). Similar integrated clinical treatment utilizing social workers as well as psychiatrists was applied to a group of juvenile delinquents, the greater percentage of whom were not markedly neurotic or deviational. 72\% remained non-delinquent. HEALY AND BRONNER, NEW LIGHT 
cedures may at least enable detection of those criminals who are presently incurable. ${ }^{76}$

One basic obstacle to satisfactory penal reform is the fact that judges are prepared neither by technical training nor tradition to prescribe the necessary individualized treatment for the mentally ill offender. 77 Initial attempts to meet this problem were largely limited to emphasis upon probation, indeterminate sentencing and parole. ${ }^{78}$ But these palliatives can aid only in rescuing the offender from initial judicial error. Without adequate preliminary diagnosis and facilities for subsequent cure, they have proved only a haphazard aid. ${ }^{79}$ From their failure, it has become increasingly apparent that the sentencing function of the criminal court should be divorced from the

on Dennguency and Its Treatarent 214 (1936). Nor was there a recurrence of criminal behavior in eight cases treated by Conn, The Psychialric Trcatment of Cerlain Chronie Offenders, 32 J. CRar. L. \& CrarnNology 631 (1942). Cases referred to such elinies are carefully selected by preliminary diagnosis. FrIEDLANDER, op. cit. stipra note 73 , at 222 . See also LeVY, Reduction of Recidivisar Through TherapY 134 (1941).

76. See p. 1096 and note 46 stpra.

77. "All the resources of [government] are available to malke a proper determination of the guilt or innocence of the accused. When, however, guilt has been established, the efforts of government seem to end. . . . A finding of guilty is a finding that the accused is an ailing member of society. He should be so treated. . . . Imagine what would happen if on the first determination of illness, all were thrown into a hospital and given the same treatment! Yet, that is what is done with those found suffering from an anti-sccial ailment" Grimson, Guilty!-Then Whiat? 26 A.B.A.J. 397, 399 (1940). Criminal court judges use the "hunch" system too often, give light sentences to those who plead guilty, regardless of individual characteristics, send good probation prospects to prison and vice versa, and on the whole do an unscientific job of sentencing. They need aid in getting case histories of offenders, and in applying such data to the defendants before them. A.B.A., (Section of Criminal Law) Prograsss and Cossurittee Reforts 37 ct scq. (1939) summarizing U.S. Atty. Gen., Sưrvey of Release Procedures, Vol. II, Probation (1939); Guudet, The Differences Between Jatdges in the Granting of Sentences of Probation, 19 TE:T. L.Q. 471 (1946). See also Pigeon, Probation and Pasole in Theosy amd Practice 76 (1942); Patterson, Psychiatric Aspects of New Proccdures ist the State of Michigan, 31 J. Crns. L. \& CRIAINOLOGY 684, 691 (1941).

78. See Elitott, Conflicting Penal Theories in Staturonx Crnomal Law 98-159 (1931) for discussion of indeterminate sentence, parole and probation in thirteen states. For description of indeterminate sentences and of non-punitive methods used in prisons, see Watte, The Pretention of Repeated Crnies 57-83 (1943). Sce also Radzinowicz, Present Trends of English Criminal Policy in The Modern Approscr to Crammin. Law, c.3 (1945). Where relatively indeterminate sentencing statutes exist, they provide for minimum and maximum limits fixed by either judge or statute. The actual length of sentence is determined by the parole board or its equivalent but the minimum is mandatory. The only absolutely indeterminate sentences- with neither minimum nor maximum term-are those provided for defective delinquents and sex offenders. See note \&S infro.

79. See Blanshard and Lukas, Probation and Psychutric Care For Adolescenti OfFenders IN NEW YoRK CITY (1942) ; Pigeon, op. cit. supro note 77. A thorough presentence investigation and facilities for treatment are necessary for successful probation and

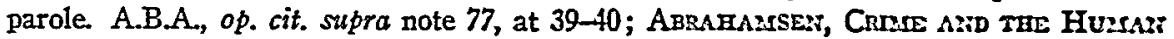
MIND 202 (1944). The necessity for some coordination of diagnosis and sentencing is illustrated by the experience at Elmira Reformatory in New York "which doesn't get re- 
guilt-finding function and turned over to experts in behavior problems. ${ }^{80}$ Although only the California Youth Correction Authority ${ }^{81}$ and Adult Authority ${ }^{82}$ Acts have incorporated such a recommendation into law, the value of assistance for the judge has been recognized in other areas. In Massachu-

formables, as it should," because courts don't select. Moran, Post-War Planning IN Probation and Parole 6 (1943).

80. S. Glueck: Principles of a Rational Penal Code, 41 Harv. L. Rev. 453 (1928), Crime and Justice 225 et seq. (1936), After-Conduct of Discharged Ofrenders 100 et

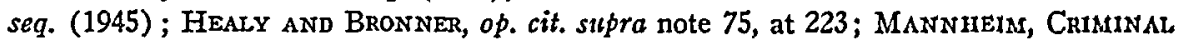
Justice ANd Soctal Reconstruction 223-37 (1946). These proposals generally provide for "treatment tribunals" made up of criminologists, psychiatrists and social workers. Sce Nordskog, Psychiatry in Criminal Trials, 17 So. CaL. L. Rev. 371, 378 (1944). It is contended that "the criminal court is . . . a clinic in human error and maladjustment" and hence it should approximate medical procedures. B. Glueck, Contemporary Isstles in the Relationship Between Psychiatry and Law, 1 J. Crm. Psychopathology 91, 99 (1939); Lindner, Stone Watus and Men 397 (1946). See also Biddle, Injustice in the Coutriroom, Collier's, May 19, 1945, p. 11, col. 1.

81. Cal. Welfare and Institutions Code c.1, Div. 2.5 (Deering, 1944); Cal. Penal CODE $\$ 6000-6004$ (Deering, 1941). The California program followed, with some changes, the Youth Correction Authority Act drafted by the American Law Institute and printed in A.L.I., Crrminal Justice-Youte 19-59 (1940). The A.L.I. model statute provides for completely indeterminate sentences, vesting complete discretion in a sentencing board, except for the requirement in $\$ 32(1)$ that every person committed to the Authority must be discharged before his twenty-fifth birthday unless the Authority has applied for and secured court approval of extension of sentence for a maximum of five years. It provides for commitment of offenders between 16 and 19 to a Youth Correction Authority which is to attempt rehabilitation of the offender. The California act however, does not pcrmit detention for longer than the statutory maximum for the particular crime. Another limitation upon the "treatment tribunal" idea in the California law is that the power of probation and of prescribing sentences up to ninety days is left to the court. And where a life sentence or capital punishment is specified by statute, then the court retains sentencing power. For discussion pro and con, see Lewis, The Youth Correction Authority Act-A Modcl, 28 A.B.A.J. 322 (1942) (pro) ; Hall, The Youth Correction Authority-Progress or Mcmace, 28 A.B.A.J. 317 (1942) (con) ; Perkins, Defect in the Youth Correction Authority Act, 33 J. CRIMr. L. \& Criminology 111 (1942). A trend toward such a program is noted in New York where, although a proposed Youth Correction Authority Act was defeated in 1943, a Youthful Offender Law was enacted, N.Y. CODE of CRIM. Proc. $\$ 913$ e-r. Applicable to youths of 16-19, it classes as youthful offenders (rather than criminals) those thought capable, after examinations, of becoming law-abiding citizens. No indictment is filed by a grand jury and probation up to three years is permitted. If he is not fit for probation, the youthful offender may be sent to a religious or charitable institution. If incarcerated, he is to be separated from criminals over 19. His record is not open to inspection and is no disqualification from public office. See Fuld, Amendments Dealing With Administration of Crintinal Law, 17 N.Y.S.B.A. BuLl. 201 n. 3 (1945); ABRAHAMSEN, op. cit. supra note 79, at 208 ct seq. The reasons these measures apply only to youths is apparently a practical one. According to the A.L.I. report, the same procedures should apply to adults. A.L.I., op. cit. silpra note 81, at 8. For discussion of the proposed Federal Corrections Act which would liberalize sentencing procedures in the federal courts but with more power retained by the judge, see Mannherm, op. cit. supra note 80, at 224 et seq.; S. Glueck, Indeterminate Sentence and Parole in the Federal System: Some Comments On a Proposal, 21 B.U.L. Rev. 20 (1941).

82. Cal. Penal Code $\S \S 5075-81$ (Deering, 1941). For description of the Adult 
setts, for example, a pre-trial examination of all serious or habitual offenders by psychiatrists of the State Department of Mental Diseases is required. ${ }^{83}$ And in New York, a psychiatric clinic attached to the Court of General Sessions of New York City examines every offender. ${ }^{84}$ Similar programs exist in many juvenile courts. ${ }^{85}$ In New Jersey, a central diagnostic center to which offenders may be sent for up to forty-five days before being sentenced, is extensively used by judges, even though the procedure is discretionary. ${ }^{86}$

Despite the importance of a sound classification system, it must be followed by flexible procedures in the post-classification period if treatment is to be successful. Probably the most significant beginning to solution of the entire problem has been made in the several states which have recognized the mental abnormality of one group of recidivists, the sex offenders, ${ }^{\text {st }}$ by

Authority, see Cal. Dept. of Corrections, Philosophy, Prnictples, asid Prosrass of tre CaltroRnia Adult Authority (1945). "Under Calfornia's laws, the courts sentence felons to prison but do not . . f fix the term of duration of imprisonment. [This is done by] the Adult Authority after the convicted person has served at least six months." Id. at 4.

83. MIass. Ans. Laws, c. 123, $\$ 100$ A (1942). See S. Gluecli, Psychialric Examination of Persons Accused of Crime, 36 Y ALEL.J. 632 (1927) ; Overholser, Two Y'ars' Expcrichec

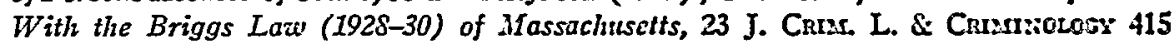
(1932).

84. The Court of General Sessions is the only one in New York State which offers pre-trial psychiatric service routinely. For description of its psychiatric clinic, see BLAs:SHARD AND LUKAS, op. cit. supra note 79, at 75-80; ABRAHAMSSEN, op. cit. supra note 79, at 202 et seq. All New York criminal courts have the statutory power to equip themselves with clinical facilities. N. Y. CoDe of Crarr. Proc. $\$ 909$. Los Angeles, Detroit, Chicago, Philadelphia and Boston also have such clinics. Gregory, Psychiatry and the Problems of Delinguency, 91 Asr. J. Psychlatry 773, 775 (1935). For reference to U.S. Distriet Court psychiatric facilities, see Wood and WaITE, Crine aNd Its Treatssent 234 (1946).

85. WoOd AND WAITE, op. cit. supra note 84, at 316-7. It has often been suggested that the real point of attack upon crime is the juvenile delinquent who is dominant among serious offenders-making up 35\% of the total in New York State. Selin, The Crnmmulity o: YouTH 23, 116 (1940).

86. N.J. Stat. ANn. $\S 2: 192-1.1, \S 30: 4 A-1-17$ (1939). See Ellis, Practical Results of the Classification Program, 32 J. CrIAs. L. \& CRIarnology 72 (1941) for deseription of classification in general and of the New Jersey Diagnostic Center in particular. Ellis points out that much expense of institutional commitment is saved by the Center's recommendation of probation for those who are believed to be good prospects. Id. at 78. New York established a reception center for youthful offenders between 16-21 at Elmira reformatory to determine which penal institution is best fitted for the individual's needs. N.Y. Cosnecrio: LAw $\$ \$ 60-4$. See Fuld, supra note 81, at 205.

87. Actually, sex offenders do not loom large in the recidivist picture although they are popularly believed to comprise the major portion. Two-thirds of sex ofienders had not served a previous prison term whereas two-thirds of burglars and auto-thicves had. Sellin, op. cit. supra note 85, at 78. See also Frosch and Bromberg, The Scx Offerder-A Psyehiatric Study, 9 A3r. J. of Orrnopsychintry 761, 770 (1939). But see W. East, Sextal Offenders-A British View, 55 YALE L.J. 527, 555 (1946) ("At present the proportion of sexual offenders and their reconviction rates compare favorably with other grougs of offenders. ...") 
enacting "sexual psychopath" commitment laws. ${ }^{88}$ These statutes provide procedures like those now used for the non-criminal mentally ill. Commitment is for an indeterminate period until a cure has been effected. If no cure is possible, then permanent segregation from society is the result, as with the insane. ${ }^{89}$ A latent Puritanism appears to be the only explanation for a statutory separating-out process which includes only "sexual psychopaths" since their mental abnormality does not differ materially from that found in other equally or even more dangerous mentally disordered criminals who make up so large a.proportion of recidivists. ${ }^{90}$ Although these statutes point

88. Car. Welfare and Institutions Code $\$ 5500-5512.5$ (Deering, 1944); ILL. ANN. STAт. § 820-825 (Smith-Hurd, Supp. 1946) ; MASs. GEN. LAws, c.123A (July 1, 1947); Mich. Stat. ANv. \$28.967 (1)-(8) (Supp. 1947); Mins. STAт. \$ 8992-184 (Mason, Supp. 1946); Orzo GEN. Code ANv. \$13451-19, 20, 22 (Page, Supp. 1946) (applies to psychopaths generally); Wash. Laws 1947, c. 273; Wisc. Laws 1947, c. 459. The statutes define sexual psychopathy in various ways. They generally require that the individual be found to be suffering from a mental disorder other than insanity or feeble-mindedness coupled with a "predisposition" or "propensity" to the commission of sex offenses. The Minnesota law attempts a more specific definition: "[Psychopathic personality] means the existence in any person of such conditions of emotional instability, or impulsiveness of behavior or lack of customary standards of good judgment, or failure to appreciate the consequences of his act, or a combination of any such conditions, as to render such person irresponsible for his conduct with respect to sex matters and thereby dangerous to other persons." Scc People v. Sims, 382 Ill. 472, 47 N.E.2d 703 (1943) (Illinois law upheld); State ex rel. Pearson v. Probate Court, 205 Minn. 545, 287 N.W. 297 (1939), aff'd 309 U.S. 270 (1940) (Minnesota sexual psychopath law held constitutional. "In the interest of humanity and for the protection of the public, persons so afflicted should be given treatment and confined for that purpose rather than for the purpose of punishment. This we believe to be true even though their mental deficiencies might not be such as to require absolving them from the cffects of the criminal statutes.") ; WaIte, The Prevention of Repeated Crrme 121-5, (1943) ; Patterson, Psychiatric Aspects of New Procedures in the State of Michigar, 31 J. CRt Is. I. \& CRININOLOGY 684 (1941) ; Recent Statutes, 39 CoL. L. Rev. 534 (1939). Bills providing for such laws have been introduced in several states: Conn. H.B. 538 (1947) ; N. Y. Senate Int. 1432, Pr. 1561 (1947). New Hampshire appears to be contemplating a reversal of this trend. In 1947, a commission was set up to investigate the causes of serious sex crime and the advisability of imposing mandatory sentences and more stringent supervision of offenders after their release. Communication to Yale Law Journal from Gordon M. Tiffany, $\Lambda$ ss't. Attorney-General of New Hampshire, Nov. 21, 1947, in Yale Law Library.

-89. If the court finds the offender to be a psychopath, it may adjourn the criminal proceeding, or suspend the sentence, and commit him to a state hospital for the insane, where he must remain until he has improved to such an extent that he will not be benefited by further treatment and is no longer a menace to the health or safety of others. CAr. WELFATE AND INST. CODE $\$ 5502.5$ (Deering, Supp. 1947). The punitive philosophy still remains, however. California, Illinois, Massachusetts, Minnesota, and Ohio permit or rcquire trial of the offender upon the criminal charge once he is cured of his illness. Only Michigan specifically prohibits trial on the original charge. Mice. Stat. Ans. \$28.967 (8) (Supp. 1947).

90. The subject of sex crime "impinges upon social morality and religious doctrine, and the ordinary citizen is tempted to appraise sexual misconduct in accordance with the manner in which it personally affronts him, rather than by its social importance or its significance as an individual shortcoming." W. East, Sexual Offenders-A British Vicw, 55 YALE L.J. 527 (1946). The amorphousness of the "psychopath" category has already been discussed in 
the direction to new procedures for handling the "sick" criminal, they tend to mislead the public into believing that only these selected offenders are mentally disordered.

But psychiatric classification and treatment is not alone sufficient for successful disposition of 'mentally disordered offenders. After the formal therapy is concluded, the assistance of other skills is required. A well integrated program of treatment would include such post-penal aids as fosterhomes, trade training and a system of after-care to combat the social and economic boycott to which the ex-convict is exposed. ${ }^{.1}$ The objective would be to avoid submitting him to the undue emotional strain resulting from returning him to the unfavorable setting which first produced his maladjustment.

Since the cooperation of the subject is essential ${ }^{22}$ regardless of the rehabilitative techniques used, many commentators have contended that the punishment implicit in prison detention is incompatible with successful treatment. ${ }^{93}$ Although the gravity of the objection cannot be gainsaid, incentives

the text. East, id. at 539, says, "Sexual offences are occasionally directly attributable to mental defectiveness, some forms of psychopathic personality, psychoneurosis, and insanity." Patterson, sspra note 88 , at 689 asks, "Why should not other psychopaths with criminal propensities, such as the emotionally unstable, liars, swindlers, etc., be given similar consideration?" These statutes, despite their progressive tone, still malse the symptom of the underlying disorder the criterion of treatment.

91. See note 108 infra for references concerning adverse environmental bucliground of most criminals. The futility of returning many juvenile delinquents to such environments makes placement in carefully selected foster homes advisable. HEALY Arn Brotis:R, of. cit. supra note 75, at 212 et seq.; Foulkes, Psychoanalysis and Crime, 22 Cnis. B. Rev. 30, 42 (1944). So also, where economic circumstance has precipitated crime, the importance of equipping the released offender with trade skills is apparent. See WaIT, TrE PaEvE::TIO:: OF REFEATED CRnTE 60-5 (1943). Lindner objects to existing trade training programs because they prepare men for already crowded fields where they are the first to be fired if there is an adverse economic wind. He urges that prisoners be trained for occupations which have labor shortages. LINDNER, Stone WaLIS Arid MLE: 476 et seq. (1946). See also DeVtne, The AMrerican JaIl 19 (1937); Lawes, Crime and Rchabilitation, 2 N.Y.S.B.A. BULL. 19, 26 (1930). A thoroughly integrated system of after-care utilizing traincd probation officers and psychiatric social workers is essential. Fnnedunzezz, op. cit. supra note 73, at 222; S. Glueck, The Significance and Promise of Probalions in Psodntion and Criminala Justice, c 1 (1933).

92. Prisoners must have a goal toward which to strive if the feeling of utter futility is to be orercome. Miller, supra note 72, at 381. See also 1 Kunpansi, TnE IrwyVIDUAL CRTMInal 292 et seq. (1935).

93. Discussing psychopaths, Miller calls attention to the fact that prison incarceration serves only to intensify the already existent frustration and hostility and causes emotional reactions of "bitter futility [and] rage... forming an almost impenetrable barrier against successful therapeutic rapport." Mfiller, supra note 72, at 379. Suggestion psychotherapy cannot be effective unless the individual has an opportunity to prove his reformation. This cannot be done under a fixed prison sentence. Newlirl; Psychothcrapy on Juvenile Delinquents, 34 J. Criss. L. \& Carnrnorogy 100, 103 (1943). See also Wrisozi and Pescor, Problears in Prison Psycriatry 47 (1939); Rees, Mintal Variotions and Criminal Behavior in Miental Agnoraraltty and Carare 1, 6 (1944). 
to cooperation are available from related penal reforms such as liberalized parole and sentencing procedures. ${ }^{94}$

It appears, then, that there now exist procedures which, if synthesized and if unobstructed by the unscientifically mechanistic recidivist laws, could provide the basis for criminal rehabilitation. Such a synthesis, already existent in Belgium, ${ }^{95}$ would require pre-sentence examination of all offenders ${ }^{90}$ at a conveniently located diagnostic center ${ }^{97}$ where offenders would be classi-

94. It has been suggested that those who do not cooperate in prison might do so if put on supervised probation. FRIEDLANDER, op. cit. supra note 73, at 221.

95. Belgian penal practice is described by Bychowski and Curran, Current Problems in Medico-Legal Testimony, 37 J. CRMr. L. \& CRMInology 16, 25 et seq. (1946). Every criminal receives a psychiatric examination. The mentally disordered offender is hospitalized or imprisoned indeterminately, with a maximum of five to fifteen years ... the length of his stay being based on his progress. The offender may request liberation every six months. Once released, he receives the assistance of offices of "social readaptation" to help him readjust to normal life. See $i d$. at 21 et seq. for description of other European penal systems. For discussion of the Russian approach, see Bcrman, Principles of Soviet Criminal Law, 56 YALE L. J. 803, 816 et seq. (1947) (persons who have committed crime while suffering from chronic mental disease, temporary insanity, or other diseases making them either incapable of realizing nature of their acts or of controlling their conduct, are subject to medical care rather than punishment); Scanlan, Soviet Criminal Law and Procedure: "Star Chamber" or Clinical Jurisprudence, 19 Rocky MT. L. Rev. 261, 271 et seq. (1947) (Russian sentencing policy towards t1onpolitical criminals reflects theory that imprisonment must be reformatory and not punitive. It regards society as participant in convict's guilt. Recidivism is normally under $15 \%$ ).

96. As indicated pp. 1104-5 supra, the Briggs law in Massachusetts requires not posttrial but pre-trial examination and only of certain offenders-those charged with homicide and previous serious felonies. Such a procedure disregards the fact that the criminal act may be only the first stage of an ongoing process in which the primitive desires of the indivilual will become increasingly difficult to satisfy and so crimes will become more serious. Reliance upon the external criminal manifestations as a guide to psychiatric examination may result in an individual, whose first or second crime, is relatively insignificant, going undetected until he becomes a difficult treatment problem. The purpose of pre-trial examination such as that in Massachusetts is to determine whether the oftender is legally responsible for his acts. See S. Glueck, Psychiatry and Criminal Laze, 14 VA. L. REv. 155, 157 (1928). But compare Spirer, The Psychology of Irresistible Impulsc, 33 J. Crim. L. \& Criminotogy 457, 462 (1943) "[If] we conceive of one of the aims of law to be rehabilitation of the offender, we need no longer strain to find excuses for certain classes of individuals whom we wish to except from punishment, for every person may be held accountable for what he has done, and the disposition of his case will be made in accordance with an established program of differential treatment.").

97. Practical problems of supply of psychiatrists, social workers, facilities, etc. militate against providing each court with a clinic such as that attached to New York City's Court of General Sessions. Therefore, a central classification center such as New Jersey's, see note 86 sitpra, would seem to be advisable if an equal spread of services to all courts is desired. For discussion of classification centers, see FrIEDLANDER, TuE Psychoanalytical Approaci To Juvenile Delinguency 194-8 (1947); East, Classification Reception Centers, 36 J. Crum. L. \& Cruminology 243 (1945); Freedman, Psychiatric Clinical Service for Penology: Comments on Recent Guidance Center Trends, 36 J. Crim. L. \& Criminology 326 (1945); Freedman, The Role of Psychiatry in 
fied into "treatment types" and recommendations made concerning the types of institutions to which they should be sent, ${ }^{93}$ the advisability of probation instead of imprisonment, ${ }^{99}$ and so forth. While its recommendations should be subject to review by the sentencing judge, it should be limited by a clear statutory mandate that only arbitrary action should be over-ruled. To attain the flexibility required for fitting treatment to the needs of each case, all sentences should be relatively indeterminate, with no mandatory minimums and provision for raising the maximum by application to the court if a dangerous offender remains incorrigible. To assure proper coordination at all stages of the sentencing process, including the application of treatment and periodic evaluation of progress with an eye towards returning the offender to society, an agency patterned after the California correction authorities would be advisable. ${ }^{103}$

Prisons, 29 J. Crms. L. \& Crarnology 352, 360 et seq. (1939); Ellis, supra note 85; Kansas legislative Council Researce Dept., a Prograzr for Kansas Prusozis 5 (1938) ; Radzinowicz, English Prison System in Tre 1 10dss: Approner To Crizrivil LAw, c. 9 (1945). Excellent classification systems are reported to exist in Indiana, Michigan, New Jersey, and the Federal prison system. MacCormick, Adult Offenders in SOCIAI WORK YEAR BOOK 33, 38 (1943). The charge has been made that the classifieation idea ... has degenerated in most prisons to a farce Indower, Srosie Walls Asid MEN 404-5 (1946).

98. The objective of pre-sentence diagnosis or classification is to prescribe proper treatment for the individual offender taking into account his life-history and his particular malady. Since considerable differences appear among individuals, the trend of progressive prison systems is toward diversified institutions-each fitted for certain types of offenders. Wilson and Pescor, Problears in Prison Psychintry 37 et scq. (1939). "The better road camps, the reforestration projects in California, Pennsylvania, Washington and Wisconsin, the state prison farms of Maryland, New Jersey, North Carolina and Tennessee ... and the Federal camps and correctional institutions demonstrate the possibility of more widespread use of minimum and medium security facilities." The typical state prison today, however, "is still a walled institution in which the prisoners are quartered in cells and are employed in maintenance work, in a few industries, and on small farms in the immediate vicinity of the prison proper." MacCormicl, supro note 97, at 37. See also DEVINE, THE AMrerican JAIl (1937). The English Borstal System for youthful offenders has been described as a model of integrated classification and treatment. Radzinowicz, English Prison Systen in Tre Moders Approacr to Crusmal Lnw, c 9

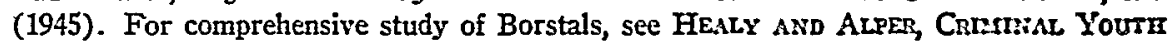
AND THE Borstal Systear (1941). The need for "near-jails . . and near-hospitals ... to provide the environment needed for selected groups of personalities rather than for specified types of crime . . ." is pointed out by Gregory, supra note 84, at 780. For description of psychiatric facilities in federal prisons, see 2 MLACConsuch, HAsweoos of Ajurrican Prisons and Reforanatories 39 et seq. (1942).

99. For discussion of accurate probation and parole prediction techniques, see $S$. Alid E. Glueck, Criattinal Careers in Retrospect, c. 15 (1943); Laume, Predictinic CrizsINALITY (1936); Hakeem, Glueck Method of Parole Prediction Applicd to 1,861 Cases of Burglars, 36 J. Crar. L. \& Crrartiology 87 (1945).

100. CAI. PENAI CODE $\S \S 5001-5003$, 5075-5084, 6000-6004, 6025-6029 (Deering, Supp. 1947). The California Department of Corrections is empowered to integrate probation, parole, pardon and prison treatment procedures. It is given broad authority to study the entire subject of penology with the object of rehabilitzting offenders. See 
An immediate objection to such a program is that, by delegating so much power over individuals to an administrative agency, there will be created considerable potential for encroachment on civil rights. ${ }^{101}$ In addition to traditional civil liberties problems such as discrimination, bribery, etc., there inheres in the utilization of psychiatric techniques the problem of protecting individual personalities from abuse. Political criminals such as dissentients in time of war, revolutionaries, and conscientious objectors typify the area in which popular hysteria might severely strain such a system. But actually, there results little increase in discretionary power over disposition of a criminal, for at one point or another, much of this power must be exercised in any criminal law procedure. ${ }^{102}$ Only the power to detain an offender as long as he remains dangerous is added. It would seem that sound personnel policies together with provision for periodic judicial review as a prerequisite for raising an initially fixed maximum could minimize arbitrary exercises of power.

Another possible objection to a rehabilitative penal system geared to personality reconstruction may be framed in terms of a reluctance to remold the offender's personality to conform to socially acceptable patterns. ${ }^{103}$ This reluctance may be rooted in an unconscious conviction that man achieves stature and dignity only out of stubborn imperfectibility, or it may stem from a belief that society advances to the degree that it gives the broadest scope to individual deviations from the norms of a given period. However, the great weight of opposition to programs of individualized treatment has not rested upon these grounds but rather upon widely held notions of primitive retributive justice. ${ }^{104}$ And it has become increasingly apparent that

Warren and Daniels, California's New Penal and Correctional Law, 32 CaLrs. L. REv. 229 (1944). There exists at present a lack of coordination among agencies dealing with the criminal. Amserican Law Institute, Criminal Justice-Youtr 12 (1940); Lewis, Youth Correction Authority Act-A Model, 28 A.B.A.J. 322, 323 (1942).

101. See Radzinowicz, The Persistent Offender in THE MODERN Approncr to CrunsINAL LAw 167 et seq. (1945); Hall, The Youth Correction Authority Act-Progress or Menace, 28 A.B.A.J. 317 (1942) (chief argument against the Act is its failure to prescribe statutory maximum sentences.).

102. At present, such discretion, with the exception of the indeterminate maximum, may be exercised by judges and probation officers if the offender is not imprisoned, or by parole boards after the statutory minimum has passed, or by the Governor under his power of pardon. It is proposed to integrate all these functions within a single agency composed of scientifically trained personnel. Such an integrated agency will undoubtedly make more intensive use of reformative techniques. It is also important to note that in non-surgical methods of treatment, the need for the patient's cooperation may be a considerable check to abuse.

103. See Hali, Princtples of Crimrtinal law 50-4, 569 et seq. (1947).

104. The view has often been expressed that the public gives only lip service to reformation but is really interested in revenge and so demands repressive prisons. "To surround the imprisoned men with an atmosphere in which reformation is possible and at the same time to make him definitely ... uncomfortable is the task of his kecpers." Wirson ANd Pescor, op. cit. supra note 105, at 41 et seq. See also authorities cited in note 1 supra. 
existing penal practice actually does change and distort the personality of offenders. Instead of attempting to channelize behavior into socially desirable activities, existing practice succeeds only in intensifying criminality.

\section{Conclusion}

Instead of welcoming any process of diagnosis and treatment of offenders that is more promising than the "almost bankrupt procedures now employed by society," 105 the criminal law has long ignored the implications of advances in psychiatry. With the development of a constructive course of treatment for a large number of criminals, the desirability of repealing the recidivist laws and thoroughly revising penal practice becomes clear. The objective of such reform would be to empty the prisons as much as medically possible. ${ }^{100}$ It should be recognized that immediate and practical problems of personnel ${ }^{107}$ and financing will confront such sweeping reform. Compensating, however, will be the probability that the penal system will at last ap-

105. S. and E. Glueck, Introduction to LINDNEs, REREL WITHOUT A CAUSE 7 (1944). Knowledge of criminals is in advance of techniques used. See Stearns, Mcdical and Sacial Factors in Crime, is Ind. L. J. 283 (1943). See Comment, Analy'sis of Legal and Medical Considerations in Commitnent of the Mentally III, 56 YALE L. J. 1178 (1947) for example of how psychiatry can be used to revise procedures for commitment of the non-criminal mentally ill.

106. It has been suggested that about three-fourths of all inmates could be released on supervised probation without endangering society. WIIsors Asd PEscon, Prostexss Ist PRISON PsyChIatry 263 et seq. (1939). This is based upon the conviction that most criminals are mere law-breakers who transgress only once as the result of sudden mental stress or economic pressure. Several writers contend that a system of fines and costs would be adequate deterrence for such offenders. See LinpNek, STOrre Waurs Ast XIE: 397 (1946) ; MicKenna, Problenns of Pusishment, 110 Jusr. P. 366 (1946). In contrast to parole, probation deals with offenders "not yet squeezed into the sad shapes imposed on humans by the typical prison matrix." S. Glueck, The Significance and Promisc of Probation in Probatton and Crnornal Justice 1, 4 (1933).

However, probation is still not accepted as a means of trestment for adult felons. During a period of twenty years, there was little or no increase in the number of such offenders placed on probation. Mloran, Post-War Planninic Is Propamo: ard Parore 7 (1943). Some farsighted judges utilize such methods to refer selected cases to psychiatrists. for treatment. Conn, The Psychiatric Treatment of Corlair Chronic Offerdcrs, 32 J. CRTAr. L. \& Crmanology 631 (1942). The practicability of probation is indieated by the report that of the $31 \%$ of offenders who were recommended for probation by the psychiatric clinic of New York's Court of General Sessions, 92\% were successes. MiacCormick, Adult Offenders, in Socral WORE YEAs BOoK (1943). For excellent discussion of probation by a British magistrate, see Mururrs, Crnare ars Psichology 47-65 and passin (1944). See also Symposium, Conzretion and Probation, 19 CANr. B. REv. 499 (1941). It has been suggested that instead of following the present trend of placing criminals in already overcrowded mental hospitals vis sexusl psychopath commitment laws, more psychiatrists should staff the prisons. Patterson, Psychisiric Aspects of New Procedures in the State of MFichigan, $31 \mathrm{~J}$. Crna. L. \& Cnnmionoax 684, 692 (1941).

107. There is a shortage of psychiatrists in the nation as a whole as well as in the prisons. Addition of numbers would enable prison psychiatrists to undertalie treatment 
proach its professed aim of rehabilitation instead of expending vast sums upon punitive measures which only intensify the problem.

Without claiming that psychiatry can cure all criminals, and recognizing that there are first offenders and recidivists who are not mental cases at all, the contribution of psychiatry can still be considerable. Application of its classification procedures will not only permit segregation of incurables but will also aid in preventing "normal" criminals from being transformed into recidivists by a damaging prison regime. So also may intensive study of mentally ill offenders assist in understanding and in developing effective treatment techniques for normal offenders.

Although the need for importing medical techniques into the penal system is urgent, psychiatry alone cannot solve the problem of crime. The high incidence of criminality among products of broken homes and unfavorable environments ${ }^{108}$ indicates that widespread social reform is necessary if society is to progress from after-the-fact cure to prevention of the disease before

rather than be compelled by inadequate staff and facilities to restrict themselves to diagnosis as is now the case. Most states have no psychiatric services in penal institutions where rehabilitation is supposed to occur. Lukas, Comments on the Attitude of the Legal Profession Toward Psychiatry, 5 LAw. GuILd REv. 301, 306 (1945). At present, prison psychiatrists "usually have to deal with so heavy an intake that their work is largely diagnostic, with little time for therapy." MacCormick, supra note 97, at 37. See also Blanshard and Lukas, Probation and Psychiatric Care for Adolescent Offenders IN NEw YoRk City 69 (1942); Lawes, Crime and Rehabilitation, 2 N.Y.S.B.A. BuLl, 19, 26 (1930). Experience under the "sexual psychopath" commitment laws, discussed on p. 1105 supra indicates the ease with which inadequate facilities can frustrate a program of rehabilitation. Thus, in Illinois, only 30 odd cases have been prosecuted under that law since 1938. Among the reasons given for its failure is the following, ". . . most psychiatrists would be reluctant to invoke it by sworn court testimony, because although the act says that the commitment is to be for purposes of treatment, no facilities are available in our present prison set-up." Communication to the Yale Law Journal from Dr. D. B. Rotman of Psychiatric Institute of Municipal Court of Chicago, Sept. 5, 1947. Similarly, in California, "The State hospitals do not report any great success in the treatment of sexual psychopaths. One reason for this is that the limited personnel has prevented us from giving these patients the intensive treatment they need." Communication to Yale Law Journal from Dr. Lawrence Kolb of Cal. Dept. of Mental Hygiene, Sept. 18,1947 , in Yale Law Library.

108. See Jones, The Social Problem Group, 23 CaN. B. Rev. 177 (1945) ; Wrottesley, After-Conduct of Discharged Offenders, 61 L. Q. REv. 373, 374 (1945). Traditionally, the background is described as marked by divorced, alcoholic or mentally disordered parents, unfavorable neighborhood and companions, lack of economic opportunity, etc. Thompson, A Psychiatric Study of Recidivists, 94 Axr. J. Psycuiatry 591 (1937); S. GiUECK, op. cit. sitpra note 31 , c. 2 . It has been estimated that $59.4 \%$ of inmates come from "disintegrated" families. Breguet, Preliminary Strvey of 1000 Case Histories of Inmates of Elmira Reformatory, 1 AM. J. MEd. JuRIs. 101 (1938). See also HEALY AND Bronner, NEW Light on Delinguency and ITS TreatMrent 201 et seq., especially at 203 (1936). "There is no fundamental difference between the delinquent and the normal man save that the former has as a rule greater difficulties and less opportunity than we who have to treat and judge him." Rees, Mental Variations and Criminal Bchavior in Mental Abnormality and Crime 7 (1944). 
it develops. ${ }^{109}$ Nevertheless, utilization of psychiatry and other rehabilitative techniques will minimize the problem as it appears within the existing societal framework. ${ }^{110}$

109. "If we would change the amount of crime in the community, we must change the community." Tannenbaun, Carnie and the Comasunity 25 (1938). The conception of delinquency as an attractive mode of behavior looms large in American movies and press. The glorification of wealth regardless of how it is acquired is also said to contribute to America's high delinquency rate. HEALY AND BRosnsER, op. cil. stpro note 10S, at 218. It has been pointed out that criminals represent in exaggerated form the egocentricity which characterizes our society. Thompson, A Psychialric Study of Recidivists, 94 Aar. J. Psychiatry 591 (1937).

110. The trend of criminal treatment has been likened to that of the insane. "When medical science made clear the nature of mental disease ... . brutal methods were abandoned but at the same time society was protected by keeping the insane safely in institutions. . . Later, as science revealed more of the causes, a constructive course of trestment was inaugurated." Pigeon, Probation and Parole m Theosy asto Practice 187 (1942). 